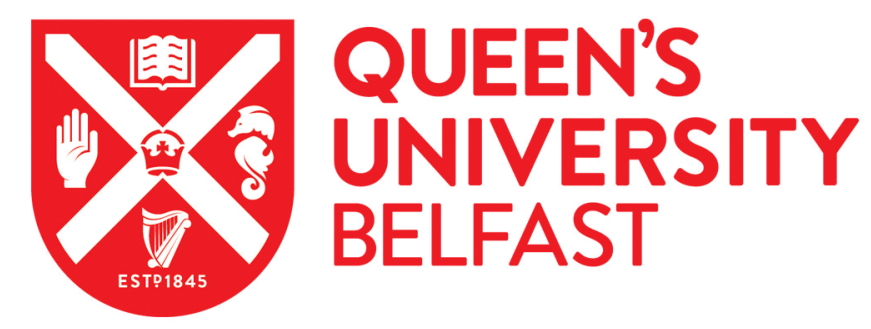

\title{
The paradox of 'teaching' transformation in fine art studio practice: assessment in the South African context
}

Belluigi, D. Z. (2014). The paradox of 'teaching' transformation in fine art studio practice: assessment in the South African context. International Journal of Education Through Art, 10(3), 349-362.

https://doi.org/10.1386/eta.10.3.349_1

Published in:

International Journal of Education Through Art

Document Version:

Peer reviewed version

Queen's University Belfast - Research Portal:

Link to publication record in Queen's University Belfast Research Portal

Publisher rights

(C) 2014 Intellect.

This work is made available online in accordance with the publisher's policies. Please refer to any applicable terms of use of the publisher.

\section{General rights}

Copyright for the publications made accessible via the Queen's University Belfast Research Portal is retained by the author(s) and / or other copyright owners and it is a condition of accessing these publications that users recognise and abide by the legal requirements associated with these rights.

Take down policy

The Research Portal is Queen's institutional repository that provides access to Queen's research output. Every effort has been made to ensure that content in the Research Portal does not infringe any person's rights, or applicable UK laws. If you discover content in the Research Portal that you believe breaches copyright or violates any law, please contact openaccess@qub.ac.uk. 


\section{The paradox of 'teaching' transformation in fine art studio practice: assessment in the South African context}

\section{Introduction}

Since the end of apartheid, a dominant discourse in both the South Africa contemporary art and higher education landscapes is one of transformation. Utilising the specificity of fine art studio practice, this article explores how despite political, social, ethical or historical imperatives to transform or affect change, too easily educational systems unconsciously and unwittingly reflect, reproduce and recreate 'norms', despite attempts to challenge, redefine or recreate them. Educators often approach teaching and learning relationships by mimicking the way they were taught or the way they learnt, in a cycle where academics create images of themselves. Such reproduction is further exacerbated in South African education by traces of colonialism and apartheid's educations outdated philosophy of homogeneity, where for the dominant group to be privileged, it excluded, normalized or domesticated divergence.

Healthy suspicion of techno-rationalist discourses and audit cultures is certainly important. However the current vacuum of critical dialogue around issues of change within the creative arts in higher education in South Africa is disconcerting. Informed by theories and debates within higher education studies, including the published perspectives of art educators and researchers internationally, in this article I argue that without concerted effort to critically reevaluate assessment practices within South African art institutions, the potential of and for the reflexive transformation that is espoused within curriculum content and arts practice, will remain at a remove from pedagogical processes and pragmatics. This is a paradox of the 'form' of fine art studio practice pedagogy not being in reciprocal and reflexive dialogue with its 'content'. 
The article is structured in such a way as to provide the reader a sense of the wider and particular contexts and pragmatics of this paradox. It commences by placing the discussion within the context of transformation in South African higher education, and then more particularly, how fine art curricular shifts have occurred in response to this and more global concerns. The espoused curriculum's concern with issues of power and its aim for developing critical citizenry, identified by critical and postmodern approaches in education as central to agential transformation, is discussed. The article's focus then enlarges the subject of assessment, as a means to uncover the hidden curriculum, including the adoption and negotiation of referential frameworks for assessment. Looking more fundamentally, assumptions and approaches to judgement within assessment communities are explored, before making tentative suggestions as to how the paradox may be acknowledged and perhaps addressed.

\section{Transformation in South African higher education}

The university holds the potential to act in a critic role. However, since the $70 \mathrm{~s}$, it has been widely recognized that educators may be complicit or collude with structures that seek to maintain rather than challenge the status quo. Through the impositions of institutional power in education, this has either outright excluded or at the very least alienated students who are constructed as 'others' in relation to the homogenising 'norm'. Underlying this is an Enlightenment conception of the unique, autonomous, centered self - a logic of identity that often excludes and marginalizes that which is different to itself. Pertinent to this paper, in South Africa's colonial and apartheid past, whiteness hegemony constructed and enabled the white, heterosexual male as the ideal self, constraining and disadvantaging those that differed as 'other', creating injustices in which education was and often still is complicit.

It is in this climate of 'the unfinished agenda of South Africa's struggle for liberation' (Aitchison 2005: 13) that academics informed by the critical tradition and postmodern 
notions of adult education persevere with their belief in the potential of education for transformative learning, change and autonomy (Usher \& Johnston, 1997). In the South African higher education sector, quality assurance discourses have been explicitly linked with transformation following the 1994-elections. It was believed that 'a comprehensive transformation of higher education was required, marking a fundamental departure from the socio-political foundations of the previous regime' (CHE 2004: 230). Nationally, both neoliberal and social justice discourses have emerged, evidencing a tension between transformation as more responsive to the demands of the global economy, or as sensitive to the diverse social, historical and cultural needs of the country. It is the social justice mandate which is most congruous with art education, as it echoes many of the issues and concerns explored in South African artmaking, during and after apartheid. Similar notions of 'justice, citizenship and community’ (Barnett 2000: 50) have been echoed in international shifts towards making higher education more accessible to those previously excluded from or disadvantaged by such systems. More than this simply being about entry or formal access through registration and attendance, there has been a desire to understand how access to knowledge may be democratised by granting students 'epistemological access' to the knowledge processes of the university (Morrow 2009). This is not simply about the students 'induction' into one academic culture, as previously was the case with the few 'ideal' students, but rather an acknowledgement that within formal education there are a range of diverse, contradictory, at times competing and often implicit cultures, conceptions and structures of knowledge that students have to learn to negotiate to survive. How this national imperative and mandate has been negotiated within fine art studio practice is the subject of this article. 


\section{Unearthing some of the complexities in fine art studio practice curricula}

In this article I argue that a paradox exists in most South African art curricula, where content is chosen to encourage students to engage with critical issues, but where this very content is nested within teaching, learning and assessment practices that themselves have not been opened to transformatory processes. Individual educators are more influenced, unconsciously and implicitly, by systems and educators who they were taught by, than by conscious theories or philosophies (Bourdieu 1990). This is often more so in studio teaching and learning (Barrett 2009), where enculturation is an integral part of the apprenticeship dynamic. As I discuss within this article, traces of past traditions of art education from the medieval workshop guild, to the various academies and Bauhaus, ghost current teaching and learning practices.

Post-structural analyses of curricula have unearthed that, more often than not, there is more than one curriculum intertwined in formal education - the formal curriculum and other hidden versions (Eisner 1986; Sambell \& McDowell 1998; Belluigi 2008). Practices are underpinned by assumptions, values and practices, which may or may not be consciously part of the education process, and so may be in conflict with the espoused theories of the curricula or the philosophies of those who teach. The 'hidden curriculum' involves the more subtle process of inculcating students with non-cognitive aspects of learning, such as values, tastes and beliefs. It is at this fundamental level that epistemological challenge or disruption is required, for 'transformation' to be more than strategic lip-service.

Because of the understanding that assessment communicates what is valued by, and perhaps even determines, the hidden curriculum and is the moment where power is exerted or negotiated, it has been recognised as a 'site' to excavate and reveal hidden assumptions. In general higher education circles much energy has been directed towards reforming or innovating assessment to create alignment or articulation between that espoused and that 
practiced. Internationally, this has led to a proliferation of research around assessment in art, with particular attention given to the critique (or 'crit' as it is colloquially called) in fine art, and its counterparts in such cognate disciplines as architecture and design. However despite the interest of the transformatory potential of assessment nationally, very little discussion, debate or research has emerged from the arts higher education sector in South Africa, where the crit and assessment by exhibition retain their central position. What makes the crit a pressing issue is that as an 'oral genre' is an integral part of the fine art curriculum, not an add-on method as assessment is often viewed in other disciplinary contexts. It is centralised within the studio tradition and its acculturation rituals are "the means by which this academic discipline performed its culture, relived its historical roots, and socialized newcomers into the traditions' (Dannels 2005: 152). What is of interest is how such aspects of the hidden curriculum (mis)fit with the theories espoused in fine art studio practice curricula.

\section{Espoused theories of fine art curricula}

Many agree that there is little uniformity of pattern across the variety of art curricula today (such as Elkins 2001; Dallow 2003; Harwood 2007), so that attempting to typify current art curricula becomes an impossible, if not redundant, task. One of the reasons for contemporary curricular values in art education evidencing little consensus is an ontological/ epistemological problem at the heart of art curricula. Whilst many established disciplines are concerned with determining what remains within the canon or content of the course or its pedagogical objectives, visual arts is concerned with defining art itself (Baldacchino, 2008; Harwood, 2007). Art education's approach to traditions can be visualised across a continuum, with absolutism on one end (which is where music may be placed), and relativism on the other (which is where visual art may be placed) (Elkins 2001; Harwood 2007). Absolutism as the conservation of tradition holds that there is a generalisable canon, a standpoint critiqued for its modernist attempts at homogeneity and grand narrative style. Instead relativism as the 
innovation or destruction of tradition holds that curricula should be responsive to the surrounding culture or context, a standpoint critiqued for being revisionist. As visual art schools attempt to respond to changes in the art world as quickly as possible, this suggests that the possibilities for transformation in art education are immense. However, as this article explores, while the content of the curricula have changed, assessment practices have mostly remained unchanged.

Finding echoes in the binary of the university as ivory-tower versus being responsive or held accountable, this division between absolutism and relativism can be linked to formalist and contextualist approaches to artmaking, which greatly influence art educators (Anderson \& McRorie, 1997). Similarly, these echo tensions between modernist medium-specific interest and postmodernist discourse-interest in contemporary art (Foster 1996). With formalism, form is seen as the content of the work, which acts universally to communicate pleasure, beauty, truth. Contextualism posits the meaning and worth of art in the context in which the work was constructed (by artist and viewer), that is in the context of its cultural, historical, social, or political functions.

With the move towards relativism, contextualism and a discourse-interest within contemporary art schools, curriculum content has shifted away from historicism as the 'inculcation of precedent' to multidisciplinary explorations of contemporary cultural conditions and contexts (Dallow 2003: 58), where students are required in their artmaking to ask questions drawn from aesthetics, semiotics, ethnography, sociology and cultural theory. Critical discourse in fine art curricula are centred on the artworks of students and artists, with dimensions of inquiry into social issues (such as race, gender, ethnicity) serving to interrogate, challenge and shape the artist-student's personal and cultural connections. In South African art institutions, this shift has in the main occurred only in the past two decades, 
with a particular concern around the politics of representation and different 'knowledges' (such as enlarging and challenging those valued and privileged in formal education, to be inclusive of knowledge constructed by different sub-cultures and belief structures, within various indigenous knowledge systems).. This 'look[ing] beyond the structures of their discipline or the interests of the individual to society' is in an attempt to build critical consciousness (Toohey 1999: 65) and have transformatory effect. In this way, the students' artmaking processes are intended to echo the process of the contemporary artist as reflective practitioner (Schön 1983) in the professional community of practice.

What this demonstrates is that the espoused theories of current art education in higher education are influenced by aspects of the critical tradition and postmodern of adult learning. It should be kept in mind that many current 'western' art curriculum models came about after WWII. This historical import, reinforced by ideas fundamental to anti-apartheid art, is felt most keenly by those curricula influenced by the critical tradition, where 'ideology critique' is seen as central to the educational project - a stripping away of consciousness in dialogue with others, so as to understand the nature of the students' positioning, develop 'true' consciousness and take action to change a situation. Curricula influenced by postmodern notions of education and the fluid, contingent self, are in agreement with certain aspects from the critical tradition but may depart radically from others (Usher \& Johnston 1997). As with the critical tradition, there is a concern with power, and the politics and problematics of the ways in which representation influences how we produce ourselves as active 'subjects' and/or 'objects' of power. Part of the educational experience is to position formal knowledge and the student experience as mutual and dynamic, in a process of critical reflexivity. Experience is not seen as 'text' to be read \& (re)interpreted, but rather a site of struggle over meaning and significance. 
For contemporary art curricula to embody their espoused theories, they should in theory adopt teaching, learning and assessment approaches which question structures that disempower the student (the critical tradition), and enable the inclusion and positionality of discourse and the personal narratives of students (postmodern notions). However assessment, a crucial and revealing pivot within curricula, exposes the paradox of much current fine art pedagogy in the South African context.

\section{Focusing on the referential frameworks of assessment practices}

A most contentious current issue in South African higher education is how outcomes-based education (OBE) impacts on the referential frameworks for assessment, and the push away from norm-referenced assessment (NRA) to criterion-referenced assessment (CRA). NRA involves a comparative approach between members of the student body to determine how well the individual fared against his/her peers. CRA involves determining how the individual's work has fared against the purpose of the course or assessment, most often with explicit criteria used for reference. Ipsative assessment, another approach to referential frameworks common in fine art studio education, is where comparisons are made with the student's previous performance to chart development. The re-emphasis on CRA was an attempt to shift assessment from a focus on normative comparisons to one on individual learning, which in South Africa was linked explicitly with a discourse of transparency as opposed to elitism. Assessment is still predominantly norm-referenced in national fine art studio education, with any shifts often being strategically adopted because of national requirements. As with international trends, these have mostly occurred at the technical level (processes and methods) and not fundamentally in terms of teaching and learning (Delandshere 2001). Others argue that the opposition created between norm and criterion referenced assessment simply feeds into a myth of objectivity (Shay 2005) which privileges the latter, and erases some of the subtle interplays between them which occur in practice. Because much of art making involves 
unpredictability, some argue that neither referential framework is appropriate because they both involve comparison (Eisner 1993). In this discussion, I privilege neither, but rather hope to show that referential frameworks cannot be seen as isolated from the larger purposes and assumptions that underpin their contextual use.

NRA has been common practice in fine art adult education since the medieval guild's dependence on the discretion of masters and influence of patrons. The master-apprentice discursive positions involve elements of the 'deference' an inferior subordinate displays to acknowledge the formal status of his/her superior (Webster 2005). An effective means for acculturating students, this mimetic teaching tradition has been criticized for absenting student voice and aspirations (Harwood 2007). Despite this, the construction of studio supervisor-student as a master-apprentice dynamic is still prevalent in art education.

NRA systems have continued throughout the traditions. The origins of many art competitions, such as the Absa L'Atelier and Sasol New Signatures in South Africa, can be traced to the original highly competitive award systems of the French Academy's Grand Prix and the Prix-de-Rome. Art historians have noted that such norm-referenced competitions most often foster uniformity and discourage experimentation. Most local competitions continue to follow practices problematic since the Carracci Academy, where competitions were judged in private and the resulting order was recorded without comment. With this practice, as Carracci articulated, assessors intended to soften 'the bitterness of being criticized' (Elkins 2001: 11). However experience of the unfairness of having decisions 'handed down' without explanation or appeal, and Romantic accusations of NRA as authoritarian and negatively normative of individual potential and direction, were possibly instrumental in provoking the modern system of critiques. 
Concurrent have been instances of CRA, where pressures from academia created requirements for more supposedly 'objective' methods. Unlike systems which depended on patrons for their existence and in turn their informal assessment processes, the French Baroque assessment practices involved a rational system of analysis with clear criteria and mark weighting. However this transparency was not underpinned by the current democratic and transformatory intentions of CRA, rather it reinforced a strong system of reproduction, with an emphasis on drawing skill attained through copying, memorizing and 'accuracy'. The 'reproduction' tradition which emerged from this system holds that creativity can only be learnt through reproducing the work of past masters with the assistance of tutors, emphasizing craft over intellect or originality (Cowdroy \& De Graaff 2005), thereby reasserting dominant value systems.

The status of the master-teacher increased as it was formalized from guiding apprenticeship to academic study. This sense of prestige and power was further increased with colonial expansion, so that by the late $18^{\text {th }}$ Century varied forms of art education existed in many parts of Europe and its colonies (Stankiewicz 2007), such as South Africa. It is possibly because of this that studio supervisors still attach value to this 'atelier' model which constructs the studio supervisor as an expert coach. Against the reproductive effects of its assessment practices, the espoused theory of this model involves offering constructive one-on-one criticism on ideas and proposals towards realizing students' ideas, where the student's artwork becomes the medium for the learning process, on which the creative processes, aesthetics and critique are focused.

This focus on the students' rather than the masters' work is evidence of the larger shift that occurred from the master as practicing artist (and employer) in the guild to the master as teacher at the academy. However aspects of both these dynamics continue to ghost current 
practices in studio teaching and learning. Informal and close personal relationships are seen by some as an expected student-supervisor dynamic and as a major advantage of the studio, however questions as to the value of this relationship extend from the current systems back to the $19^{\text {th }}$ Century Romantic academies. In addition to concerns about the importance of the 'master's' influence, another contemporary complication of the model has to do with the current diversity of students. In her study, Webster found that supervisors felt the coach model could only be enacted for those students who were already fully acculturated and highlevel (Webster 2004) - that is, students who mirror their supervisors' identities, abilities or values.

The 19th-century École des Beaux Arts was the first to adopt a 'jury' system where a panel of 'experts' made a collective judgement about the quality of a student's work, a system of assessment by proxy that was subsequently adopted in many art schools. Still central to the pedagogy of 'western' fine art, design and architectural education is this crit method of assessment (otherwise known as 'review', or 'dialogue'). At the time this was based on a verbal presentation of the artwork made by the student's studio master, but was adapted in the postwar period so the students themselves began to present and 'defend' their own work. More recently, methods such as portfolios, which record learning and research processes, have been added as complimentary methods to diversify assessment in UK, US, Canadian and Australasian art education, but not extensively in South Africa.

The current lack of discussion in South Africa around assessment in fine art, may possibly be due to a resistance to assessment stemming from Romantic and modernist paradigms of art education, which are based on notions of the artist-student as innately unique and expressive. Assessment is constructed as imposing values and standards which negatively impact on expression, creativity and the 'wow' factors (Gordon 2004). Such prescription seems to fly in the 
face of the distinctiveness or individuality of art works themselves (Cannatella 2001) and notions that art education should be mostly concerned with 'cultivating students' productive idiosyncrasies' or diversity (Eisner 2007: 425). Where assessment has been arbitrary and authoritarian, this hostility may be justified. However the legacy of modernist practice persists in the prevalent use of an uncritical god-like perspective to assessment where

all-knowing judgements can be made without fear of contradiction or due consideration being given to the complexity of the cognitive processes in relationship to how both procedural and declarative forms of knowledge have been used, and the criteria and other values students have drawn on to inform the working process (Cunliffe 2007: 95).

To explore the possibilities and problematics for transformation in assessment, it is necessary to uncover the assumptions and approaches to assessment which may be fundamental to, but also go beyond, the context of fine art studio pedagogy or South Africa in particular.

\section{Assumptions and approaches to judgement}

Tensions within assessment practices may be found in the roots of different philosophical assumptions, i.e. the traditional, objectivist, utilitarian, positivist, scientific movement in education; and more subjectivist, intuitionist, constructivist assumptions (Gray 2002). Positivist assumptions and the construction of assessment as a technology have been heavily critiqued from those within the latter stream, who view assessment as a socio-political practice whose purpose is defined within a structure and context and as an act of cultural communication about the values of society.

Some see the interpretivist approach to assessment as most appropriate for fine art (Orr 2010) as it involves the negotiated judgement of a process or a product within a framework of shared understandings (Hickman 2007). This is a notion of criticism and discourse that depends on a 'stable interpretative community' (Fish 1980), i.e. a group of people within a particular context who are likely to agree amongst themselves, on such issues as taste, values 
and quality for instance, for a duration of time. However, as much as connoisseurship within an interpretative community offers possibilities, some crucial concerns can be raised, particularly when it comes to the possibilities for transformation. Extending from art education's early history, notions of the connoisseur gaining expertise over time through exposure within an interpretative community has appropriately been termed 'guild knowledge' (Sadler 1989). As such, assumptions that academic communities of practice can approach anew or transform assessment practices should perhaps be questioned, particularly in the face of a lack of scholarship on assessment in art education (Price 2005).

Locating this approach in the South African context adds further complications, where the majority of art educators in higher education are still white or come from middle to upper class backgrounds. Integral to issues of identity, community and judgment, is the sociopolitical, theoretical and philosophical context within which assessment is situated. What is most problematic is that as value judgements are defined by socio-political contexts, through being exercised, they reproduce the social structure. Bourdieu $(1977,1984,1988)$ argues that education involves a strong current of acculturation, where 'habitus' (as disciplinary dispositions) 'leads us to "reproduce" the social conditions of our own production' (Bourdieu 1990: 87). Many studies have pointed to the exclusionary practices and unequal relationships between students and lecturers within fine art, where the tacit acceptance of this imbalance may even be crucial to the acculturation role of the crit (Percy 2004). Those with social and cultural capital are accepted as promising future members of the community, while those who are not, become alienated from the discourse and performance of the assessment practices. In the South Africa context, this may further disadvantage those students from black, unemployed/ working class backgrounds or first generation university students. However, some argue that a more positive view of 'cultural capital' may create possibilities for power differentials within communities to be recognised and reversed (Horton 2007). With revision, 
it is argued that the crit in particular can become an event that explicitly and consciously provides students with epistemological access (Percy 2004), and may promote political and social values amongst students (McCoy 1993).

A further critique of the interpretivist stance is that it may not be reflective of the reality of the contemporary postmodern art world which is characterised by difference, conflict and change. Interpretation in the interpretivist tradition is situated around meaning, while postmodernist notions suggest that interpretation occurs through positioning oneself within discursive practices (Gooding-Brown 2000). Because assessors act as 'representatives' of different interpretative communities, assessment in fine art studio practice actually operates within an 'avanescent interpretative community' (Elkins 2001). Unlike modernist attempts to separate the viewer, artwork and assessment from discursive practices, what this postmodernist notion does is to recognise potential openings for interaction between them. This may allow for is reflexive self-awareness, where 'the viewer engages with the artwork in such a way that awareness of one's own and other's positioning in the discursive practices of the text occurs in order to understand self and difference from self' (Gooding-Brown 2000: 47). This then becomes an issue of ethical relations, of the relationship and interplay between self and other, a crucial concern within the assessment debate, particularly in South Africa where such polarities and constructions persist. In addition, postmodernist challenges to knowledge claims allow for acknowledgment of the inherent revisibility of knowledge(s), crucial when exploring the potentials for transformation through assessment. A far more tentative, conditional approach allows for some revision and calls for more deliberation, debate and challenge (Danvers 2003). In this way, issues of difference, representation and identity can be used as tools to explore practice, both in terms of artmaking practice and teaching practice. 


\section{Addressing the paradox}

Judgment is a contentious issue, both in terms of criticism of contemporary art and in terms of assessment of student artworks. While the procedures of assessment have remained fundamentally unaltered, changes in the purposes of assessment reflect transformations in society. Recent drives in higher education away from the narrow focus on summative purposes and from the competitive position of identity and social status inherent to NRA, are reflective of the influence of the critical tradition and an attempt to be inclusive of a more diverse student body, with a desire to see assessment as student-learning focused. However, as I've discussed, such a shift is not evident in current assessment practices in South Africa which are shadowed by the 'fossilised' 'legacy of the past' (Delandshere 2001: 130). Many dismiss talk of privilege and injustice as in the past (whether that be colonialism, modernism, apartheid et cetera), othered from the concerns of the present. However, informed by the collective memories and common sense assumptions of the society in which either they or their parents grew up, many academics on both sides of the racial divide may require a disruption of patriarchal traditions not to continue reproducing inequalities unconsciously. Moreover I would argue that such disruption is required not only on an agential level', but more substantively, by interrogation of the very assumptions that underpin curricular structures and cultures, such as those evidenced in current assessment practices.

Without concerted effort towards reflexive practice, studio supervisors, as the 'authors' of curricula and other pedagogical structures and methods in higher education, will most probably default back to that which they learnt or experienced in their own assessments as students, reproducing normative values from their perspective 'which accords with the author's self-perception and cultural experience' (Webb 1996: 97). The 'ideal' student is the person who finds out how to demonstrate that which is most valued by the assessor, while those who do not either fail outright or learn in superficial or strategic ways without deep 
understanding. This sense of the teacher being self-(in)formed remains teacher- or curriculum-centred rather than inclusive of the goals of the diversity of students and is therefore inherently non-transformatory and non-pluralistic. So whilst fine art studio practice curricula preach and sometimes even problematize transformation, assessment practices indicate that a questioning of pedagogical assumptions and constructions has not yet occurred.

A promising turn is towards the project of a politics of difference. Postcolonial and feminist challenges (amoungst others) to homogenous, Eurocentric traditional fields of inquiry have created awareness that 'society and culture have been the heterogeneous product of heterogeneous people in an enormous variety of cultures, traditions, and situations' (Said 1993: 310-311). Recognising education as a form of cultural politics (Aronowitz \& Giroux 1985), enables a plethora of other conceptions, so that teaching and learning becomes cultural exchange between those of different backgrounds (education/ socio-economic/ geographic), personalities, beliefs (religious/ secular), learning styles, gender, sexual orientations, ages etc. Assessment spaces, in particular, are complex cultural sites that possess the potential for occupying liminal zones of transgressive practices where identities are negotiated - spaces of counterpressures and counternarratives (McLaren 1995).

Postmodernist notions may allow for a 'co-constructivist' concept interconnecting students with each other and their studio supervisors with various different knowledges, experiences and communities. This sense of the 'artist as collaborator' (Hardy 2006) recognises the educator-artist and student-artist as commentator, constructor and interpreter of the Culture Industry. With this comes interaction, exchange, fluidity, and the discovery of liminal spaces and alternate relationships between individual, community and ideas. Transformatory potential lies in the critical accent that learning is not only about connections but also about 
challenging and disrupting norms, and that such challenges extend beyond the 'content' to the 'form' of curricula. Such shifts in power may exacerbate an anxiety already articulated by art educators, caused by the radical philosophical shifts in terms of the nature of art (Pistolesi 2001; Schiralli 2002). However, the old adage of 'practicing what one preaches' holds here, where studio supervisors as both artists and educators could model a critical awareness of the politics of their practice and methods, as is expected of art students in their artmaking. One of the ways to go about reflective practice is to engage in critical conversations with fellow fine art studio practice teachers nationally and internationally, as South African dialogue and research into art higher education is sorely lacking. Such conversations would revive a valid tradition of teaching that is as old as the early academies.

\section{Conclusion}

In this article, I have placed my argument for re-thinking the current inherited practice of teaching, learning and assessment in fine art studio practice, within the post-colonial, postapartheid context of South African higher education. By embedding the discussion within this context, crucial concerns which underpin the critical traditions in education, such as transformation and social justice, emerge as paradoxically in tension with assessment practices. I drew the article to a close by suggesting that within postmodernist approaches there are possibilities for the form of teaching practice to be reciprocally related with the content or conceptual concerns of the curriculum in ways that may more validly negotiate the relationships of power.

\section{Reference list}

Aitchison, J. (2005). 'It's not inside, it's on top!' At the Margins of Adult Education, Work and Civil Society ,Jensuu, University of Jensuu. 19-22 May, 2005.

Anderson, T., \& McRorie, S. (1997). A Role for Aesthetics in Centering the K-12 Art Curriculum. Art Education, 50(3), 6-14. 
Aronowitz, S., \& Giroux, H. A. (1985). Education Under Siege: The Conservative, Liberal, and Radical Debate Over Schooling. South Hadley, Mass: Bergin \& Garvey.

Baldacchino, J. (2008). The Praxis of Art's Deschooled Practice. Journal of Art \& Design Education, 27(3), 241-250.

Barnett, R. (2000). Supercomplexity and the curriculum. Studies in Higher Education, 25(3), 255-265.

Barrett, T. (2009). About art interpretation for art educators. Studies in art education, 42(2), 5-19.

Belluigi, D. Z. (2008). Excavating the 'critique': An Investigation into Disjunctions Between the Espoused and the Practiced Within a Fine Art Studio Practice Curriculum. Unpublished thesis, Grahamstown, Rhodes University, http://eprints.ru.ac.za/972/01/BelluigiMEd2008.pdf . Accessed 5 December 2012.

Bourdieu, P. (1977). Reproduction in Education, Society and Culture. Newbury Park, Calif: Sage. Bourdieu, P. (1984). Distinction: A Social Critique of the Judgement of Taste. Cambridge, Mass: Harvard University Press.

Bourdieu, P. (1988). Homo Academicus. Cambridge: Polity Press.

Bourdieu, P. (1990). In Other Words: Essays Towards a Reflexive Sociology. Cambridge: Polity Press.

Cannatella, H. (2001). Art Assessment. Assessment \& Evaluation in Higher Education, 26(4), 319-326.

CHE (Council on Higher Education). (2004). South African Higher Education in the first decade of democracy. Pretoria: Council on Higher Education.

Cowdroy, R., \& De Graaff, E. (2005). Assessing highly-creative ability1. Assessment \& Evaluation in Higher Education, 30(5), 507-518.

Cunliffe, L. (2007). Towards a more complex description of the role of assessment as a practice for nurturing strategic intelligence in art education. In T. Rayment (Ed.), The Problem of Assessment in Art and Design. Bristol: Intellect Books.

Dallow, P. (2003). Representing creativeness: practice- based approaches to research in creative arts. Art, Design \& Communication in Higher Education, 2(1/2), 49-66. 
Dannels, D. P. (2005). Performing Tribal Rituals: A Genre Analysis of '“Crits"' in Design Studios. Communication Education, 54(2), 136-160.

Danvers, J. (2003). Towards a Radical Pedagogy: Provisional Notes on Learning and Teaching in Art \& Design. Journal of Art \& Design Education, 22(1), 47-52.

Delandshere, G. (2001). Implicit Theories, Unexamined Assumptions and the Status Quo of Educational Assessment. Assessment in Education, 8(2), 113-133.

Eisner, E. W. (1993). Reshaping assessment in education. Journal of Curriculum Studies, 25, 219-233.

Eisner, E. W. (2007). Assessment and evaluation in education and the arts. In L. Bresler (Ed.), International Handbook of Research in Arts Education (pp. 423-426). Springer.

Elkins, J. (2001). Why Art Cannot Be Taught: A Handbook for Art Students. Urbana: University of Illinois Press.

Fish, S. E. (1980). Is There a Text in This Class: The Authority of Interpretive Communities. Cambridge, Mass: Harvard University Press.

Foster, H. (1996). The return of the real: the avant-garde at the end of the century. Cambridge, Mass: MIT Press.

Fullan, M. (1993). Change forces: Probing the depths of educational reform. London: Falmer Press. Gooding-Brown, J. (2000). Conversations about Art: A Disruptive Model of Interpretation. Studies in Art Education, 42(1), 36-50.

Gordon, J. (2004). The 'wow' factors: the assessment of practical media and creative arts subjects. The 'wow' factors: the assessment of practical media and creative arts subjects, 3(1), 61-72. Gray, P. (2002). The roots of assessment. Tensions, solutions, and research directions. In T. W. Banta (Ed.), Building a Scholarship of Assessment. San Francisco, Calid: Jossey-Bass.

Hardy, T. (2006). Introduction: Nailing Jelly: Art Education in a Postmodern world. In T. Hardy (Ed.), Art Education in a Postmodern World: Collected Essays. Bristol: Intellect Books.

Harwood, E. (2007). Artists in the academy: curriculum and instruction. In L. Bresler (Ed.), . Dordrecht: Springer. 
Hickman, R. (2007). (In defence of) whippet-fancying and other vices: Re-evaluating assessment in art and design. In The Problem of Assessment in Art and Design. Bristol: Intellect Books. Horton, I. (2007). The Relationship between Creativity and the Group Crit in Art and Design Education. Presented at the Creativity or Conformity? Building Cultures of Creativity in Higher Education, Cardiff, the University of Wales Institute and the Higher Education Academy, www.creativityconference07.org/tabled_papers/Horton_Relationship.doc . Accessed 13 January 2011.

McCoy, K. (1993). Countering the Tradition of the Apolitical Designer. In J. Myserson (Ed.), Design Rennaisance: Selected Papers from the International Design Congress. Presented at the The International Design Congress, Glasgow: Open Eye Publishing.

McLaren, P. (1995). Critical Pedagogy and the Pragmatics of Justice. In M. Peters (Ed.), Education and the Postmodern Condition. London: Bergin \& Garvey.

Morrow, W. E. (2009). Bounds of Democracy Epistemological Access in Higher Education. Cape Town, South Africa: HSRC Press.

Orr, S. (2010). 'We kind of try to merge our own experience with the objectivity of the criteria': The role of connoisseurship and tacit practice in undergraduate fine art assessment. Art, Design \& Communication in Higher Education, 9(1), 5-19.

Percy, C. (2004). Critical absence versus critical engagement. Problematics of the crit in design learning and teaching. Art, Design \& Communication in Higher Education, 2(2), 143-154.

Pistolesi, E. (2001). Good art education is good art. Art Education, 54(5), 11-17.

Price, M. (2005). Assessment standards: the role of communities of practice and the scholarship of assessment. Assessment \& Evaluation in Higher Education, 30(3), 215-230.

Sadler, D. (1989). Formative assessment and the design of instructional systems. Instructional Science, 18, 119-144.

Said, E. W. (1993). Culture and Imperialism. London: Chatto \& Windus. 
Sambell, K. \& McDowell, L. (1998). The Construction of the Hidden Curriculum: messages and meanings in the assessment of student learning. Assessment \& Evaluation in Higher Education, 23(4), 391-402.

Schiralli, M. (2002). Anxiety and Uncertainty in Aesthetic Education. Journal of Aesthetic Education, $36(2), 52-66$.

Schön, D. A. (1983). The Reflective Practitioner: How Professionals Think in Action. New York: Basic Books.

Shay, S.-E. (2005). The assessment of complex tasks: A double reading. Studies in Higher Education, 30(6), 663-679.

Stankiewicz, M. A. (2007). Capitalising art education: Mapping international histories. In L. Bresler (Ed.), International Handbook of Research in Arts Education. Dordrecht: Springer.

Toohey, S. (1999). Designing Courses for Higher Education. Philadelphia, Pa: Open University Press. Usher, R., \& Johnston, R. (1997). Reconfiguring the other. Self and experience in adult education. In R. Usher, I. Bryant, \& R. Johnston (Eds.), Adult Education and the Postmodern Challenge. Learning Beyond the Limits. London: Routledge.

Webb, G. (1996). Understanding Staff Development. Buckingham: Society for Research into Higher Education.

Webster, H. (2004). Facilitating Reflective Learning: Excavating the Role of the Design Tutor. Journal of Art, Design and Communication in Higher Education, 2(3), 101-111.

Webster, H. (2005). The Architectural Review. Arts and Humanities in Higher Education, 4(3), $265-$ 282. 